* Doutora em Direito Civil Comparado pela Pontifícia Universidade Católica de São Paulo (PUC-SP). Mestre em Direito Negocial pela Universidade Estadual de Londrina (UEL). Professora da Graduação e Pós-graduação e Vice-Coordenadora do Mestrado em Direito Negocial da Universidade Estadual de Londrina (UEL). E-mail: anaclaudiazuin@live.com.

** Mestranda em Direito Negocial pela Universidade Estadual de Londrina (UEL). Especialista em Direito do Trabalho pela Universidade Anhanguera (UNIDERP). Bacharel em Direito pela Universidade Estadual de Londrina (UEL). Advogada. E-mail: nathpontelli@hotmail.com.

\section{RESPONSABILIDADE CONTRATUAL E CLÁUSULA GERAL DE REDUÇÃO DA INDENIZAÇÃO À LUZ DA TEORIA CONTEMPORÂNEA DO INADIMPLEMENTO}

\author{
CONTRACTUAL LIABILITY AND THE CLAUSE \\ OF REDUCTION OF THE IMNDENITY IN \\ LIGHT OF THE CONTEMPORARY THEORY OF \\ DEFAULT
}

\author{
* Ana Cláudia Corrêa Zuin Mattos do Amaral \\ **Nathalia Nunes Ponteli
}

Resumo: A responsabilidade civil assume especial relevância na sociedade atual, ao surgir como instrumento apto a restabelecer o equilíbrio social diante de danos causados pela inobservância de dever geral de cautela ou pelo inadimplemento contratual. Objetivando proporcionar amplo ressarcimento, foram desenvolvidos mecanismos que flexibilizam a verificação dos pressupostos da responsabilidade e ampliam a proteção à vítima. Todavia, a redução equitativa da indenização, prevista no parágrafo único do artigo 944 do Código Civil, atua como limitador à reparação integral do dano, quando houver desproporção entre este e a culpa do lesante. Este trabalho analisa se, diante da teoria contemporânea do inadimplemento contratual - que reconhece a ocorrência da culpa pelo mero descumprimento voluntário do pactuado entre os contratantes - será aplicável o mencionado dispositivo às hipóteses de responsabilidade contratual e, sendo cabível, quais os limites a serem observados.

Palavras-chave: Responsabilidade civil. Redução da indenização. Responsabilidade contratual.

Abstract: Civil liability is particularly relevant in today's society as it emerges as an instrument, which restores social balance in the face of the damage caused by a breach in the general duty of precautionary measures or by a contractual default. Aiming to provide ample compensation, mechanisms were developed to mitigate the verification of the assumptions of responsibility, which extends to the protection of the victim. However, the equitable reduction of compensation is provided for in the sole paragraph of the Article 944 of the Brazilian Civil Code and it acts as a limiter of the damage's full compensation 
when there are disproportions between damage and guilt. This study aims to examine whether - in the face of the contemporary theory of contractual default, which recognizes the occurrence of guilt by mere voluntary breach of the contract between parties - this aforementioned device would be applied to cases that involve contractual liability, and, what are the limits, where appropriate, that need to be observed.

Keywords: Civil liability. Reduction of imndenity. Contractual liability.

Como citar: AMARAL, Ana Cláudia Corrêa Zuin Mattos do; PONTELI, Nathalia Nunes. Responsabilidade contratual e cláusula geral de redução da indenização à luz da teoria contemporânea do inadimplemento. Scientia Iuris, Londrina, v. 20, n. 1, p.165-193, abr. 2016. DOI: 10.5433/2178-8189.2016v2 0n1p165. ISSN: 2178-8189. 


\section{INTRODUÇÃO}

O instituto da responsabilidade civil vem se consolidando nas últimas décadas como um dos mais relevantes na sistemática do Direito Civil atual, na medida em que constitui mecanismo apto à pacificação e restabelecimento do equilíbrio social, constantemente abalado em razão dos inúmeros danos decorrentes da ampliação das relações humanas, públicas e privadas, em volume e complexidade. Tal realidade é consequência direta do surgimento de uma sociedade globalizada, econômica e culturalmente, ligada em rede, com transmissão instantânea de dados, informações e produtos, criando um risco constante de violação de direitos e interesses juridicamente relevantes, causando danos que atingem amplo alcance, muitas vezes provocados por relações de consumo ou contratos de adesão.

A fim de assegurar o mais completo ressarcimento às vítimas, o Código Civil brasileiro adotou o princípio da reparação integral, que estabelece que todo dano deve ser indenizado ou compensado, trazendo satisfação ao lesado, que reconhece o amparo estatal ao direito violado, e punição e desestímulo ao ofensor, evitando assim sua reincidência.

Todavia, a despeito da adoção do princípio da reparação integral, o Código Civil de 2002 prevê no parágrafo único do artigo 944 a possibilidade de redução da indenização quando observada a excessiva desproporção entre a culpa e o dano. Tal dispositivo legal é admitido no ordenamento jurídico como cláusula geral apta a promover a relativização do princípio da reparação integral, autorizando a redução equitativa do valor da indenização a critério do julgador, mediante análise do grau de culpa do ofensor em contraposição à gravidade do dano causado.

A aplicação da redução equitativa da indenização, no entanto, está longe de ser tema pacificado na doutrina e jurisprudência, na medida em que implica em aparente ofensa à ideia de justiça corretiva prevista por Aristóteles - que se constitui na busca pela manutenção da igualdade entre as partes na relação entre particulares, cuja inobservância resultaria em consequências visando o restabelecimento do equilíbrio maculado - muito presente até os dias atuais quando se trata do ressarcimento de danos.

Em meio às divergências acerca da possibilidade de aplicação do parágrafo único do artigo 944 um tema de inegável relevância se destaca: se seria possível a aplicação da redução equitativa da indenização para os danos 
decorrentes de inadimplemento contratual e, neste contexto, como o elemento culpa deve ser compreendido.

\section{A RESPONSABILIDADE CIVIL CONTRATUAL NO DIREITO BRASILEIRO}

O instituto da responsabilidade civil, cuja origem encontra raízes na ideia de justiça corretiva de Aristóteles, funda-se na violação de um dever jurídico de observância obrigatória e que cause dano a outrem, fazendo nascer um novo dever jurídico, dito secundário: o de reparar o dano.

Nas palavras de Cavalieri Filho (2012, p. 2) “em apertada síntese, responsabilidade civil é um dever jurídico sucessivo que surge para recompor o dano decorrente da violação de um dever jurídico originário".

Desde o direito romano observa-se a criação de mecanismos que tinham como objetivo restabelecer o equilíbrio das relações jurídicas entre particulares em caso de violação de direitos que resultem em danos. A Lei das XII Tábuas e a Lex Aquilia traziam a previsão expressa de reparação para a prática de alguns delitos, como a damnum iniuria datum (dano à coisa alheia animada ou inanimada), a qual ensejava a reparação pecuniária pelo dano causado ao proprietário, através do simples ressarcimento (se houvesse a confissão do ofensor) ou à condenação em dobro (se houvesse a negativa deste e prova em contrário), conforme destaca (SANSEVERINO, 2010, p. 21).

Inicialmente, a reparação do dano assumia caráter predominantemente punitivo, demonstrando que o foco do instituto estava na função pedagógica em relação ao ofensor e não na satisfação/compensação da vítima (PARGENDLER, 2004, p. 5).

O modelo de responsabilidade civil que conhecemos na atualidade, com a separação dos ilícitos civis e penais e com a prevalência da função satisfativa da indenização surge com a edição do Código Civil Francês de 1804, modelo acolhido e reproduzido pela maioria dos países com legislação civil codificada, inclusive pelo Brasil:

No existía en las leyes bárbaras un principio general en materia de responsabilidad civil, Tampoco en las antiguas costumbres francesas se advierte un sistema distinto del estabelecido por el derecho romano, según el cual no había un concepto de delito 
sino delitos diversos y su correspondiente tabla de rescate impuesta obligatoriamente al autor y a la víctima. [...] Más aún, no se distinguió en Francia sino bastante tiempo después, alrededor del siglo XII, el delito civil del delito penal.

Demogue dice que en la segunda mitad del siglo XII fue cuando se puso en claro la separación de la reparación y de la pena.

[...] Tratándose de los delitos privados la acción reconocida a la víctima conservaba en muchos casos carácter penal, particularmente en aquellos hechos que por atacar a la persona y atentar contra el honor concitaban el espíritu de venanza. Esa acción era la de reparación civil, que se distinguía netamente de la acción por indemnización de daños y perjuicios. La primera era de carácter penal y correspondía ao precio de la sangre persiguiendo el castigo del ofensor, La segunda no tenía ya carácter penal sino resarcitorio de los daños ocasionados a los bienes.

[...] Los redatores del Código Civil francês siguieron el cauce del antiguo derecho. Fue así que quedó definitivamente establecida la distinción entre pena (sanción represiva) y reparación civil del daño (sanción resarcitoria). También fue princípio incontrovertido que todo daño debe ser reparado por aquél por cuya culpa fue ocasionado (ALSINA, 1997,

${ }^{1}$ Tradução livre: "Não havia nas leis bárbaras um princípio geral em matéria de responsabilidade, tampouco nos antigos sistemas aduaneiros franceses algo diverso do estabelecido pelo direito romano, segundo o qual não havia o conceito de delito, mas vários delitos e correspondente tábua de salvação obrigatoriamente imposta ao agressor e da vítima. [...] Além disso, não se distinguiu na França, senão algum tempo depois, por volta do século XII, o delito civil do delito penal. Demogue afirmou que somente na segunda metade do século XII tornou-se clara a separação de reparação e punição. [...] No caso de delitos privados a ação assegurada à vítima preservada em muitos casos o caráter penal, particularmente naqueles casos em que o ataque à pessoa e a violação da honra despertavam o espírito de vingança. Essa ação era de reparação de danos civis, que se distinguia claramente da ação de indenização por perdas e danos. A primeira possuía natureza penal e correspondia ao preço do sangue perseguindo a punição do infrator, a segunda não tinha natureza criminal, mas ressarcitória de danos materiais. [...] Os redatores do Código Civil francês seguiram o curso da lei antiga. Foi assim que ficou estabelecida definitivamente a distinção entre a pena (punição repressivo) e a reparação civil (sanção ressarcitória). Também tornou-se princípio incontroverso que todo o dano deve ser reparado por aquele cuja culpa o ocasionou" (ALSINA, 1997, p. 47-50).

2 No período anterior ao Código Civil de 1916, a responsabilidade civil era atípica. Nesta fase, a reparação de danos era baseada em norma alheia ao Direito Civil, utilizando-se o artigo 22 do Código Penal de 1830, que determinava que "a satisfação será sempre a mais completa que for possível". 


$$
\text { p. } 47-50)^{1} \text {. }
$$

Desde a inserção da responsabilidade civil no ordenamento brasileiro, com o advento do Código Civil de $1916^{2}$, observa-se significativa evolução do instituto, pois se a princípio o legislador estabeleceu expressa previsão dos danos indenizáveis, restringindo a interpretação ampliativa e trazendo grande dificuldade na aceitação do cabimento de indenização para danos não arrolados no código, a Constituição Federal (1988), promoveu verdadeira revolução ao admitir a indenização de danos extrapatrimoniais, mudanças estas que foram consolidadas com a edição do Código Civil de 2002, com a utilização de cláusulas gerais de responsabilidade civil objetiva e subjetiva, além da tipificação específica de alguns danos, sem, todavia, estabelecer um rol taxativo dos danos indenizáveis (SANSEVERINO, 2010, p. 26-27).

O Código Civil de 2002 admite duas formas de responsabilidade civil: contratual e extracontratual, sendo que em ambas há violação de um dever jurídico preexistente, de modo que a distinção entre uma e outra estará na gênese desse dever.

A responsabilidade contratual estará evidenciada quando o dever jurídico violado estiver previsto no contrato firmado entre as partes. Pode-se afirmar, portanto, que responsabilidade contratual não está no contida no contrato, como alguns a definem, mas tão somente o dever jurídico preexistente, resultante de obrigação originária voluntariamente assumida pelas partes contratantes, cujo descumprimento por qualquer delas faz nascer o dever de indenizar (CAVALIERI FILHO, 2012, p. 305).

Observa-se, portanto, que a diferenciação entre responsabilidade contratual e extracontratual reside na origem do dever violado. No mais, tudo o que existe na responsabilidade extracontratual - conduta (que pode ser culposa ou não), nexo causal e dano - também se verifica na responsabilidade contratual, mas "se a transgressão se refere a um dever estabelecido em negócio jurídico, a responsabilidade será contratual; se a transgressão é de um dever jurídico imposto pela lei, a responsabilidade será extracontratual" (CAVALIERI FILHO, 2012, p. 305).

\footnotetext{
${ }^{3}$ Tradução livre: "Em conclusão, a área de responsabilidade contratual é reforçada neste breve excursus com respeito á todas as situações nas quais a cláusula geral de boa fé cumpre uma função integradora da regulação contratual e nas que é a lei mesma que prevê os deveres específicos de comportamento em presença de uma relação obrigatória preexistente á estrutura complexa, tal como se tratou de definir as páginas precedentes. Em todos os demais casos existe responsabilidade extracontratual".
} 
Em conclusión, el área de la responsabilidade contractual es reforzada en este breve excursus con respecto a todas las situaciones en las que la cláusula general de buena fe cumple una función integradora de la regulación contractual y en las que es la ley misma la que prevé los deberes específicos de comportamento en presencia de una relación obligatoria preexistente a la estrutura compleja, tal como se ha tratado de definir en las páginas precedentes. En todos los demás casos existe responsabilidade extracontractual (VISENTINI, 1999, p. 237) ${ }^{3}$.

Em relação ao surgimento da responsabilidade civil contratual e extracontratual, Rui Stoco $(2011$, p. 164) destaca que os romanistas não conseguem precisar de forma satisfatória qual dessas espécies teria precedido à outra, ou seja, "se primeiro nasceu a responsabilidade delitual, de que a contratual foi consequência; ou se foi o contrato a fonte primeira da obrigação, surgindo mais tarde a responsabilidade delitual".

A despeito da controvérsia acerca da origem das espécies de responsabilidade civil, a similitude entre elas deu origem a teoria que defende que a responsabilidade é sempre e necessariamente delitual e que a expressão responsabilidade contratual seria errônea, diante da identidade de princípios e elementos que regulam ambas as formas de responsabilidade (CAVALIERI FILHO, 2012, p. 306).

Todavia, apesar da similaridade de determinados elementos em ambas as espécies de responsabilidade, ainda prevalece o reconhecimento da existência de sua divisão em contratual e extracontratual ${ }^{4}$.

\footnotetext{
${ }^{4}$ A prevalência da diferenciação da responsabilidade em contratual e extracontratual, tal como ocorre no Brasil, pode ser percebida também em outros ordenamentos jurídicos, como o italiano, pois em que pese o art. 2056 de seu Código Civil declare aplicáveis aos dois tipos de responsabilidade alguns critérios limitativos de ressarcimento, tornando secundária a diferença de valoração do dano no que concerne à diferenciação das responsabilidades, na realidade, cada tipo de responsabilidade continua a desenvolver seu próprio sistema. Assim, tendo em vista o que foi dito não se pode dizer que não há diferenças de regulação entre a responsabilidade contratual e extracontratual sendo que estas se evidenciam com relação à diferente função dos dois tipos de responsabilidade e diria que são diversas também no que tange ao ressarcimento do dano. De maior importância são aquelas que resultam dos efetivos usos jurisprudenciais do que as que derivam dos textos legislativos na matéria. De qualquer modo, não se pode dizer que atualmente a distinção entre responsabilidade contratual e extracontratual se tenha superado; é importante aclarar que as diferenças entre os dois tipos de responsabilidade persistem, mas não são as declaradas e difundidas oficialmente pelo legislador de 1942 (VISINTINI, 1999. p.252).
} 
Aceitando-se ou não a teoria da identidade de elementos entre as espécies de responsabilidade civil, surge, em face da ampliação das hipóteses de ressarcimento, a necessidade da análise da aplicabilidade da cláusula geral de redução equitativa da indenização aos danos oriundos da violação de deveres jurídicos contratualmente estabelecidos e qual o papel da culpa nestes casos específicos, visto que a aferição de sua desproporção em relação ao dano mostrase essencial para a incidência do parágrafo único do artigo 944 do Código Civil.

\section{CONSIDERAÇÕES SOBRE A TEORIA CONTEMPORÂNEA DO INADIMPLEMENTO CONTRATUAL}

Pode-se afirmar que o inadimplemento das obrigações é fonte originária de danos de diversas espécies, os quais devem ser reparados nos moldes estabelecidos pelo instituto da responsabilidade civil.

Prevê o Código Civil de 2002 no tocante ao inadimplemento que "não cumprida a obrigação, responde o devedor por perdas e danos, mais juros e atualização monetária segundo índices oficiais regularmente estabelecidos, e honorários de advogado" (artigo 389). Nota-se, ao estabelecer encargos para o devedor que não observar os termos pactuados, uma preocupação do legislador em assegurar o pontual cumprimento das obrigações, garantindo desta forma segurança jurídica àqueles que se valem de contratos para promover a circulação de bens e serviços.

Em se tratando da conceituação, afirma-se que a "obrigação é um vínculo jurídico em virtude do qual uma pessoa fica adstrita a satisfazer uma prestação em proveito de outra" (GOMES, 2007, p. 15), ou a visualizam como "a relação jurídica, de caráter transitório, estabelecida entre devedor e credor, e cujo objeto consiste numa prestação pessoal econômica, positiva ou negativa, devida pelo primeiro ao segundo, garantindo-lhe o adimplemento através do seu patrimônio" (MONTEIRO, 2007, p. 8).

Há, todavia, que se diferenciar os conceitos de obrigação e responsabilidade, motivo pelo qual Sérgio Cavalieri Filho destaca que a obrigação é sempre um dever jurídico originário, ao qual se comprometem as partes adimplir, a responsabilidade, por outro lado, seria o dever jurídico sucessivo, consequência direta da violação do primeiro.

Se alguém se compromete a prestar serviços profissionais

a outrem, assume uma obrigação, um dever jurídico 
originário. Se não cumprir a obrigação (deixar de prestar os serviços), violará o dever jurídico originário, surgindo daí a responsabilidade, $\mathrm{O}$ dever de compor o prejuízo causado pelo não cumprimento da obrigação. Em síntese, em toda obrigação há um dever jurídico originário, enquanto que na responsabilidade há um dever jurídico sucessivo. Daí a feliz imagem de Larenz ao dizer que "a responsabilidade é a sombra da obrigação". (CAVALIERI FILHO, 2012, p. 2-3).

Desta forma, consistem os contratos em um complexo de obrigações assumidas pelas partes que, uma vez cumpridas, resultam em seu adimplemento e no atendimento de sua finalidade, sem que dele nasça qualquer forma de responsabilidade. Com seu inadimplemento, porém, não raro as partes experimentam danos materiais e imateriais, os quais devem ser ressarcidos.

Antes de tratar acerca dos efeitos do inadimplemento faz-se necessário destacar que há uma distinção entre o inadimplemento e o mero descumprimento de dever jurídico, na medida em que o inadimplemento é um descumprimento de dever jurídico precedido pela existência de relação obrigacional (SANTOS; SAMPAIO JR, 2014, p. 3).

Trata-se o inadimplemento, assim, do descumprimento da obrigação pelo credor ou pelo devedor, podendo ocorrer voluntariamente ou devido a fatores externos à vontade das partes, quando ocorre em decorrência de eventos externos à relação contratual que impossibilitam o cumprimento do que fora pactuado.

Segundo a visão clássica da teoria do inadimplemento, pode este ser considerado absoluto ou relativo. O primeiro consistiria na total impossibilidade de recebimento da prestação devida pelo credor, convertendo-se a obrigação principal na indenização correspondente. Isso porque o descumprimento da obrigação torna a prestação inútil para o credor, de modo que, ainda que prestada posteriormente, não mais irá satisfazer as necessidades deste.

No tocante aos danos decorrentes do inadimplemento destaca-se que elos prejuízos deverão se sujeitar ao dever de reparar as perdas e danos sofridos pelo credor o contratante inadimplente e/ou contratante moroso, de modo que constitui o dano pressuposto da responsabilidade civil contratual. Assim, somente haverá responsabilidade civil contratual e a consequente obrigação de indenizar quando houver prejuízo a ser reparado (DINIZ, 2004, p. 398).

No inadimplemento relativo, por sua vez, o descumprimento da obrigação nos termos pactuados não torna inútil a prestação ao credor, de modo que esta 
pode vir a ser cumprida ainda que fora dos termos iniciais do contrato. Gomes (2007, p. 197) ao tratar do inadimplemento relativo, utilizando nomenclatura diversa assegura que :

[...] cogita-se, na teoria do inadimplemento, da impossibilidade transitória. Não raro, a obrigação pode ser cumprida, e, não obstante, o devedor deixa de cumpri-la no vencimento. Embora viável, a prestação não é satisfeita pontualmente. Há, enfim, retardamento, culposo ou não, a que a ordem jurídica não fica indiferente.

Neste caso, o inadimplemento consiste no retardamento da prestação, devendo ser observados todos os encargos contratuais e legalmente previstos pela inobservância dos termos do contrato.

Em relação à classificação do inadimplemento em espécies, cabe destacar que tanto uma quanto a outra se referem ao descumprimento da prestação principal (de dar, fazer ou não fazer). Todavia, enquanto o inadimplemento absoluto decorre da impossibilidade total de cumprimento da obrigação, a mora é a sanção aplicável ao descumprimento de uma obrigação em que se verifica a viabilidade de adimplemento posterior, de modo que, mesmo que ainda não realizada a prestação, ainda é possível a satisfação do credor (FARIAS; ROSENVALD, 2008, p. 390).

A diferenciação do inadimplemento em absoluto e relativo encontra fundamento no Código Civil brasileiro, visto que tal diploma legal pontua os efeitos do inadimplemento, fazendo distinção entre os encargos da mora e as perdas e danos. A mora e os efeitos econômicos dela decorrentes se verificam quando a descumprimento da obrigação nos termos pactuados não torna inútil o objeto da obrigação, diferentemente do que ocorre com as perdas e danos, utilizadas nos casos em que ao credor não mais se aproveita a obrigação após o descumprimento da prestação.

Uma acepção mais atual da teoria do inadimplemento traz, além daquelas hipóteses em que este decorre da omissão das partes no cumprimento das prestações pactuadas, outras formas de inadimplemento, denominadas violações positivas do contrato, consistindo esta na prática de atos que ofendam o princípio da boa-fé objetiva, o qual deve ser observado em todas as relações intersubjetivas, em especial nas relações contratuais.

Conforme exposto em linhas anteriores, a relação contratual é composta por deveres primários consistentes nas prestações que fundamentam da 
obrigação pactuada, e por deveres secundários, consistentes na responsabilidade oriunda do eventual descumprimento daqueles.

Entretanto, na atualidade, reconhece-se que para além de deveres primários ou secundários, deve-se observar a existência de deveres colaterais (ou instrumentais), os quais constituem desdobramentos da boa-fé objetiva e da eticidade que devem permear as relações contratuais, gerando um dever de cooperação das partes para que o adimplemento da obrigação ocorra da forma mais proveitosa e menos onerosa para os contratantes (SANTOS; SAMPAIO JR, 2014, p. 12).

Nesse contexto, seriam exemplos de tais deveres o de informação, de exponencial relevância no âmbito das relações jurídicas de consumo; de colaboração e cooperação, segundo o qual devem as partes colaborar para o correto e mais eficiente adimplemento da prestação; de proteção e cuidado com a pessoa e o patrimônio da parte contrária no cumprimento de uma obrigação (COSTA apud SANTOS; SAMPAIO JR, 2014, p. 12).

A ideia de violação positiva do contrato como inadimplemento contratual, portanto, visa não somente resguardar as partes em relação ao descumprimento das cláusulas contratuais expressas estabelecidas entre credor e devedor, mas principalmente assegurar o respeito aos deveres colaterais, intrínsecos, oriundos de princípios norteadores das relações contratuais. Este tipo de inadimplemento, assim como ocorre com as violações negativas do contrato (descumprimento e mora) também produz efeitos jurídicos, podendo dar origem ao pleito indenizatório.

Esta noción, a la que se refere la norma general del art. $1218^{5}$, refleja en definitiva la violación de deberes, tanto contractuales como ex lege, y compreende tanto las hipótesis en que la prestácion assumida en la obligación falta totalmente, como

\footnotetext{
${ }^{5}$ Art. 1218 Responsabilità del debitore - Il debitore che non esegue esattamente $(1307,1453)$ la prestazione dovuta è tenuto al risarcimento del danno $(2740)$, se non prova $(1673,1681,1693,1784,1787,1805-2$, 1821) che l'inadempimento o il ritardo è stato determinato da impossibilità della prestazione derivante da causa a lui non imputabile (1256; att. 160).

${ }^{6}$ Tradução livre: "Esta noção, a que se refere a norma geral do art. 1218, reflete em última instância a violação de deveres, tanto contratuais como ex lege, e compreende tanto as hipóteses em que a prestação assumida na obrigação é descumprida totalmente, como aquelas em que há inexatidão na prestação, e pode ser estendida também à violação de deveres acessórios e instrumentais na execução da prestação principal" (VISINTINI, 1999, p. 238).

${ }^{7}$ Art. 1175 Comportamento secondo correttezza - Il debitore e il creditore devono comportarsi secondo le regole della correttezza (Cod. Civ. 1337, 1358).
} 
aquéllas en que hay inexactitud en la prestación, y puede ser extendida también a la violación de deberes accesorios e instrumentales en la ejecución de la prestación principal (VISINTINI, 1999, p. 238) ${ }^{6}$.

Considera ainda a autora que no direito italiano o artigo 1175 do Código Civil $^{7}$ constitui uma norma que funciona como uma cláusula geral de dever de proteção que estende a responsabilidade do devedor por violação dos deveres acessórios e instrumentais da obrigação principal (VISINTINI, 1999, p. 233).

Dito isto, ao tratar da aplicação da redução equitativa da indenização nos casos de responsabilidade civil contratual, deve-se observar não somente o inadimplemento sob a ótica da teoria tradicional (e sua divisão em absoluto e relativo), mas também a violação positiva do contrato, nas hipóteses em que a ofensa a um dever colateral causa danos à(s) parte(s).

\section{OPAPELDACULPANARESPONSABILIDADE CIVILCONTRATUAL: BREVE ANÁLISE DA QUESTÃO NO ORDENAMENTO JURÍDICO BRASILEIRO}

Quando se trata de responsabilidade civil, a culpa é um dos elementos que se destaca, eis que, para os leigos no assunto, parece lógico que somente deveria indenizar aquele que age com "culpa" para a ocorrência do dano, sendo esta na maioria das vezes compreendida como a intenção de produzir o resultado lesivo. No entanto, não coincide com o senso comum o ensinamento doutrinário acerca da necessidade de aferição de culpa em todas as hipóteses de responsabilidade (diante da existência de responsabilidade civil objetiva e pelo risco) e, tampouco, o conceito de culpa como conduta direcionada à produção do dano, podendo tal conceito, inclusive, variar de acordo com o contexto em que se insere (responsabilidade contratual ou extracontratual).

Não se pode olvidar que inicialmente, quando do nascimento da responsabilidade civil no direito romano, a culpa sequer era elemento essencial à caracterização do dever de indenizar, bastando o nexo causal entre a conduta do ofensor e o dano para a promoção do ressarcimento in natura ou em pecúnia. Explicando brevemente o caminho trilhado pela responsabilidade civil no direito romano, Alvino Lima (1960, p. 44) destaca que esta foi iniciada pela vingança, ascendendo à composição pecuniária, sem cuidar, a princípio, da culpabilidade, o que somente veio acontecer em momento posterior. Alvim (1980, p. 243) 
estabelece um paralelo da responsabilidade civil em suas linhas iniciais com a reação de uma criança contra que a feriu, afirmando que "a pessoa só tinha em vista devolver o mal sofrido sem se preocupar com a imputabilidade".

Atualmente a responsabilidade civil, como mencionado anteriormente, é compreendida como resultado da prática de ilícito civil causador de dano. Tal ilícito, por sua vez, decorre da transgressão de um dever jurídico, sendo a culpa, por seu turno, a violação desse dever jurídico por falta de cautela, constituindo desta forma um "erro de comportamento, a conduta mal-dirigida a um fim lícito" (CAVALIERI FILHO, 2012, p. 306). Ao tratar da configuração da culpa, o referido autor (2012, p. 306), citando Caio Mário, destaca que a culpa tanto pode decorrer da infração ao comando legal ou violação da declaração de vontade individual. Em ambas as hipóteses há uma norma de comportamento estabelecida, de um lado a lei (em sentido amplo) e de outro lado a declaração volitiva do indivíduo, e que a conduta operada pela vontade ao arrepio dessas normas de conduta configura a culpa.

Ainda acerca da culpa, vale frisar que:

Uma parte dela dottrina definisce la colpa extracontrattuale come mancata precisione e/ou prevenzione dell'evento. In quest'ambito si deve distinguire tra chi propone l'adozione di un critério soggetivo e chi propende per uno oggettivo

\footnotetext{
${ }^{8}$ Tradução livre: Uma parte da doutrina define a culpa extracontratual como a falta de previsão ou de prevenção do evento. A culpa consiste na contrariedade a regra de diligência e perícia ou simplesmente na falta de diligência. O que depende da definição de diligência, prudência e perícia. Como definição de prever e prevenir (evitar) o dano. Em uma diversa perspectiva a culpa é definida como criação de um risco injustificado. Outro critério de delimitação de prever e prevenir o dano é o fundado na norma violada. Na definição da jurisprudência constitui a falta de previsão do evento previsível e ou falta de prevenção do evento evitável. Critério definido segundo parâmetros objetivos, não tendo lugar para a subjetividade. Outros afirmam que a culpa consiste na contrariedade à regra de diligência, prudência e perícia ou simplesmente na falta de diligência. Entender por uma ou outra linha depende do que se entende por diligência, prudência e perícia. Em uma perspectiva diversa, a culpa é definida como criação de um risco injustificado. Quanto maior for a utilidade social da atividade e o custo de remoção deste risco, maior é o risco justificado. Entende-se importante verificar a qualidade superior ou inferior do agente, a fim de que seja possível verificar a exigibilidade ou não de um comportamento diverso do efetivamente realizado pelo agente a excluir a sua culpabilidade, aplicando-se parâmetros subjetivos.

9 Ao tratar da culpa como requisito do dano indenizável, Alvino Lima (1980, p. 245-246) traz uma gama de conceitos de culpa, sendo pertinente a observância de algumas delas para melhor compreensão da afirmação de que não há consenso acerca da definição da culpa. Segundo o autor, para Savatier "culpa é a inexecução de um dever que o agente podia conhecer e observar"; já Bevilacqua definiria culpa como "violação de um dever preexistente"; por fim, traz o autor a definição de Espínola, segundo o qual "a palavra culpa, em sua acepção mais ampla, abrange toda e qualquer violação imputável de um dever jurídico, provenha de um fato intencional ou de uma certa falta de diligência".
} 
nella valutazione dela condotta; in quest'ultimo constesto si distingue tra chi predilige una patametro astratto e chi ritiene trattarsi di criterio concreto legato ad elementi circostanziali. Altri affermano, invece, che la colpa consista nella contrarietà alle regole di diligenza, prudenza e perizia o semplicemente nella macanza di diligenza. Il contrasto tra le due impostazioni dipende, a ben vedere, dela definizione di diligenza, prudenza e perizia; esso resulta seriamente ridimensionato quando si configurino questi parametri come critério attraverso cui definire il dovere di prevedere e di prevenire il danno.

In uma diversa prospettiva si è definita la culpa come creazione di un rischio ingiustificato che sussiste quando l'utilità sociale del rischio creato ed il costo di rimozione siano superiori al rischio creato.Si ritiene oportuno a tal fine valutare le qualità superiori ed inferior del danneggiante e, dunque, viene preferito uno standard siggettivo (CAFAGGI, 1996, p. 349-354) ${ }^{8}$.

Nota-se dos excertos acima que a culpa pode decorrer da infração de um comando legal (de ação ou abstenção) ou de declaração de vontade individual, originando uma diferenciação da culpa nas searas aquiliana e contratual e consequentemente na apuração da responsabilidade nesses casos.

Apesar da tentativa de diversos autores consagrados em conceituar a culpa, Lima (1960, p. 57) frisa que são inúmeras as definições de culpa ${ }^{9}$, mas que em sua maioria estas definições possuem em comum a observância de dois elementos: um objetivo, consistente na lesão ao direito de outrem (ou a interesse juridicamente relevante, se consideradas as concepções mais atuais), e um subjetivo, que seria a previsibilidade do resultado lesivo. Mesmo considerando a existência de inúmeras definições de culpa, o autor ainda se posiciona no seguinte sentido:

[...] se, em sentido amplo, genérico, podemos dizer que a culpa é a lesão imputável do direito de terceiro, ou qualquer fato ou violação de um dever jurídico, no sentido restrito, como elemento da responsabilidade civil, a culpa é, apenas, como veremos oportunamente, um erro de conduta, um desvio da normalidade no agir ou abster-se (LIMA, 1960, p. 58). 
Importante destacar que a culpa, independentemente do conceito adotado, constituiu elemento nuclear dos ordenamentos jurídicos de ideologia liberal e individualista, posto que o dano decorrente de conduta culposa representava um mau uso das liberdades individuais, as quais deveriam vir acompanhadas da responsabilidade equivalente, sendo possível perceber um forte apelo moral na percepção da culpa como fundamento da obrigação reparatória (SCHREIBER, 2013, p. 12).

De fato, ao definir a noção jurídica de culpa, muitos autores se valiam - e ainda hoje se valem - de elementos psicológicos ou anímicos, típicos de uma avaliação moral e subjetiva da conduta individual. Assim, refere-se Chironi à culpa como um stato d'animo do agente que se pretende responsável. Salemi refere-se expressamente à relação entre psiche e o ato lesivo, como característica da culpa. Stoppato alude à culpa como um "diffetto della intelligenza". Pontes de Miranda trata da culpa como "falta de devida atenção". José de Aguiar Dias refere-se à previsibilidade do resultado como elemento insdispensável ao conceito. Karl Larenz menciona, além da previsibilidade, um "ineludível” juízo de valor do agente sobre seu próprio comportamento (SCHREIBER, 2013, p. 14).

Ao analisar culpa no direito civil brasileiro da atualidade, mostra-se de suma importância a compreensão de sua estrutura, que encontra seus sólidos pilares nos princípios da socialidade, operabilidade, eticidade e concretude, afastando-se do viés eminentemente patrimonialista do Código Civil de 1916 para servir de instrumento à concretização dos direitos de cunho social previstos na Constituição de 1988.

A partir do advento do Código Civil de 2002 passou-se a observar um processo de mudança de paradigma, em que o foco da responsabilidade civil deixa de recair sobre o ofensor para se atentar às necessidades da vítima, ensejando a criação de mecanismos de facilitação da reparação do ofendido, entre eles a relativização do papel da culpa e até mesmo do nexo causal em algumas circunstâncias.

Se no Código Civil de 1916 a culpa era elemento essencial à caracterização do dever de indenizar (juntamente com o dano e o nexo causal), 
cuja prova era de difícil materialização, especialmente para a vítima, a quem incumbia o ônus de comprovar o fato constitutivo de seu direito, no novo código se verificam diversos mecanismos de presunção ou mesmo dispensa da culpa, conforme leciona Anderson Schreiber (2013, p. 5) em sua obra "Novos Paradigmas da Responsabilidade Civil".

Trata-se de processo denominado de ocaso da culpa, o qual vem ocorrendo como consequência da erosão dos filtros tradicionais da reparação, visto que o Poder Judiciário, afirma-se, objetivando facilitar a defesa dos direitos das vítimas, vem relativizando a importância da culpa na aferição dos elementos necessários à caracterização da obrigação reparatória (SCHREIBER, 2013, p. 12).

Especificamente no tocante à responsabilidade contratual Gomes (2007, p. 174) esclarece que "consiste a culpa na infração de dever jurídico oriundo de contrato, praticada intencional ou negligentemente. Não deve ser confundida com a culpa aquiliana, na qual se funda a responsabilidade delictual. A culpa a ser considerada no capítulo da inexecução é restrita a infrações que determinam inadimplemento de obrigação contratual".

Outra diferença apontada entre a culpa contratual e extracontratual diz respeito ao ônus da prova. Diante da responsabilidade contratual, a culpa se presume, em regra. Ao credor cumpre demonstrar que a obrigação não foi cumprida, cabendo ao devedor provar que não agiu com culpa para o inadimplemento ou que se verificaram causas excludente do nexo causal (CAVALIERI FILHO, 2012, p. 308).

Para os irmãos Mazeaud (1969, p. 108), em obra traduzida para o espanhol por Santiago Sentis Melendo:

Cuando el perjuicio resulta del incumplimiento de una obligación determinada (o de resultado) - delictual o contractual -, parece que no haya necesidad de definir la culpa. Indudablemente es necesaria una culpa, pero existe por el solo hecho de que no se ha obtenido el resultado, sin que se necesite uma apreciación de la conducta del autor del daño: se ha conducido mal al no cumplir com su obligación; poço importan las imprudencias o negligencias que ló hayan llevado a no cumplir. La ley presume que el incumplimiento se debe a su hecho, y le incumbe aquél destruir esa presunción probando la existencia de una causa ajena. 
Não basta, todavia, na seara contratual a verificação da culpa para a responsabilização do contratante, sendo necessária a aferição do dano, tal como ocorre na responsabilidade aquiliana, sem que tais relações se confundam entre si. Gomes (2007, p. 186) pontua que para a ocorrência de responsabilidade contratual não basta a ação ou omissão culposa do inadimplente "mister se faz, ainda, que do seu comportamento advenha dano para o credor, porquanto a responsabilidade consiste no dever de indenizar, isto é, na obrigação de reparar o prejuízo causado", frisando ainda que não se deve confundir esse dever com aquele que decorre da prática de ato ilícito, caracterizador da responsabilidade delitual.

Observa-se desta forma que o inadimplemento do qual resulte um dano a terceiro, quando culposo, faz nascer o dever de indenizar, no momento em que se abstém o devedor do que devia fazer para a satisfação do crédito, seja em decorrência do inadimplemento absoluto, relativo ou da violação positiva do contrato.

Evidentemente que em se tratando de questões relacionadas ao ressarcimento o debate acerca da aplicabilidade do parágrafo único do artigo 944 do Código Civil deve se ater apenas e tão somente ao inadimplemento culposo, na medida em que ao inadimplemento involuntário, oriundo de fatores externos à relação obrigacional e distintos do elemento volitivo das partes, tais como o caso fortuito e força maior, há a ausência da culpa, necessária, nestes casos, ao surgimento da própria responsabilidade.

\section{DANOS NAS RELAÇÕES CONTRATUAIS: PERDAS E DANOS E CLÁUSULA PENAL}

A responsabilidade civil tem como norte a ideia de que todo aquele que infringir dever jurídico ou violar direitos e causar um dano a outrem, será obrigado a indenizar, o que se extrai da redação do artigo 186 do Código Civil de 2002.

O dever de indenizar, tanto nas relações contratuais quanto nas extracontratuais, tem como elemento essencial o dano, ou seja, a lesão a direito ou interesse juridicamente relevante. No caso dos contratos esses danos podem ser compreendidos como os prejuízos experimentados pela parte lesada em decorrência do inadimplemento voluntário do devedor da prestação. 
Afirma-se que "indenizar significa reparar o dano causado à vítima, integralmente", de modo que o objetivo de uma indenização será restabelecer, sempre que possível, o statu quo ante, devolvendo a vítima ao estado em que se encontrava antes da ocorrência do ato ilícito (GONÇALVES, 2008, p. 338). Como, em algumas situações, não é possível retornar ao estado originário, busca-se uma compensação sob a forma de indenização. Desta forma, a natureza do ressarcimento (reparação ou compensação) será apurada de acordo com a infração cometida e o bem jurídico lesado, podendo caracterizar responsabilidade contratual ou extracontratual, a depender do fato gerador do dano.

No âmbito da responsabilidade contratual, a indenização por perdas e danos limita-se aos prejuízos direta e imediatamente ligados à inexecução contratual (danos emergentes e lucros cessantes), destacando Gomes (2007, p. 187) que "o Código Civil adotou essa orientação dispondo que o princípio da causalidade imediata deve ser observado", podendo tal indenização ser substitutiva, quando não houver interesse no cumprimento extemporâneo da obrigação, ou complementar, quando se restringir a satisfazer o credor dos efeitos da mora.

Haveria, deste modo, uma necessária equivalência entre o dano experimentado pelo credor e o valor a ser apurado nas perdas e danos, através da aferição da diminuição do patrimônio do devedor com a inadimplência ou com os encargos suportados pelo credor até o efetivo cumprimento da prestação, tais como atualização monetária juros de mora, custas processuais e honorários advocatícios, sem prejuízo da pena convencional (GOMES, 2007, p. 188).

A cláusula penal, também conhecida por pena convencional, constitui pacto acessório do contrato, cujo valor não pode ultrapassar o da obrigação principal, pelo qual as partes fixam, de antemão, o valor das perdas e danos caso se verifique a inexecução culposa da obrigação.

Tal pacto, admitido em nome do princípio da autonomia privada, tem para alguns autores a função de liquidar previamente os danos oriundos do inadimplemento, enquanto outros sustentam que tal disposição tem o objetivo de reforçar o vínculo obrigacional (GOMES, 2007, p. 190). Admitida a primeira hipótese, seriam devidos os valores pactuados a título de cláusula penal independentemente da comprovação do dano, bastando a verificação do inadimplemento culposo da obrigação contratual.

Relevante valor prático possui a cláusula penal ao avaliar e liquidar as perdas e danos, de modo que "a parte inocente forra-se aos inconvenientes de maiores discussões, liberando-se, igualmente, do ônus de provar o dano e sua 
extensão" (MONTENEGRO, 1999, p. 191).

A cláusula penal pode ser estabelecida pelas para resguardá-las do inadimplemento total do contrato (cláusula penal compensatória), circunstância em que será substitutiva da obrigação principal, ou pelo inadimplemento de cláusula especial, podendo ser cobrada cumulativamente com a obrigação principal (cláusula penal moratória) (CAVALIERI FILHO, 2012, p. 316).

Não deve a cláusula penal ser confundida com a multa simples, que consiste no pagamento de valor a título de penalidade pelo descumprimento contratual, visto que este instituto não tem como objetivo o ressarcimento de danos, mas sim um agravamento da obrigação para o devedor que não observou os termos pactuados (GOMES, 2007, p. 194).

As perdas e danos, bem como a cláusula contratual, fazem referência aos danos patrimoniais experimentados pelo contratante lesado, não se estendendo aos danos extrapatrimoniais, cuja apuração necessita do prudente arbitramento judicial para fixação, sendo sobre estes que este trabalho se debruça ao tratar da (im)possibilidade de aplicação da redução equitativa da indenização.

\section{5 (IN)APLICABILIDADE DA REDUÇÃO EQUITATIVA DA INDENIZAÇÃO À RESPONSABILIDADE CIVIL CONTRATUAL}

Conforme ventilado em momento anterior, a culpa vem ganhando novos contornos e papeis diante da mudança de paradigmas pela qual vem passando o instituto da responsabilidade civil. Mecanismos voltados à sua presunção ou dispensa, a desvalorização da graduação na aferição do dever de indenizar e outras medidas visando a facilitação da defesa dos direitos da vítima vêm revolucionando a compreensão que temos do elemento volitivo para a caracterização da responsabilidade civil.

\footnotetext{
${ }^{10}$ Tradução livre: $\mathrm{O}$ art. 944, sobre modalidades de ressarcimento, é uma disposição de nova cunhagem e de grande importância. Ele confirma que o princípio de fundo em tema de responsabilidade, encontra já implícito no ordenamento brasileiro, sendo aquele do integral ressarcimento do dano por meio do pagamento de uma soma de dinheiro, o qual se faz necessário para equilibrar a perda sofrida pelo danificado. Todavia, o parágrafo único da disposição em exame introduz uma cláusula geral que autoriza o juiz reduzir equitativamente o montante do ressarcimento no caso de "excessiva desproporção entre a gravidade da culpa e o dano", uma cláusula de mitigação considerada perigosa por atribuir ao juiz um poder discricionário extremamente amplo e não ancorado nem em parâmetros vagos, como aqueles previstos pelo art. 10:401 dos Principles, com a conseqüência de que ele poderia comprometer a tutela ressarcitória dos direitos fundamentais, talvez, "subordinando-a a exigências diversas, como aquelas relativas ao mercado de seguros".
} 
Nesse contexto destaca-se que, a despeito da irrelevância da graduação da culpa na caracterização do dever de indenizar - bastando sua ocorrência, em qualquer grau, para que deva haver a responsabilização do ofensor - o Código Civil de 2002 prevê sua observância para fins de apuração do quantum indenizatório, ao prever no parágrafo único de seu artigo 944 que "se houver excessiva desproporção entre a gravidade da culpa e o dano, poderá o juiz reduzir, equitativamente, a indenização".

Referido dispositivo tem como objetivo "evitar que a reparação integral dos danos prive o ofensor do mínimo necessário à sua sobrevivência, em prestígio dos princípios da dignidade humana e da solidariedade" (CAVALIERI FILHO, 2012, p. 40).

Cabe frisar, no entanto, que a redação da norma e os critérios estabelecidos suscitam inúmeras dúvidas acerca do âmbito de sua aplicação e limites a serem respeitados, o que se destaca inclusive na doutrina estrangeira, a exemplo de Calderale (2005, p. 328-329), quando destaca que:

L'art.944, sulle modalità del risarcimento, è una disposizione di nuovo conio e di grande importanza. Essa conferma che il principio di fondo in tema di responsabilità, ritenuto già implícito nel l'ordinamento brasiliano, è quello dell'integrale risarcimento del danno sicché, attraverso il pagamentp di uma somma di denaro è necessario eguagliare la perdita súbita dal danneggiato. Tuttavia, il parágrafo único della disposizione in esame introduce una clausola generale che consente al giudice di ridurre equitativamente l'ammontare del risarcimento in caso di "eccessiva desproporzione tra la gravita della colpa e il danno", una mitigation clause ritenuta pericolosa in quanto attribuisce al giudice un potere discrezionale troppo ampio e non ancorato neanche a parametri vaghi come quelli previsti dall'art.10:401 dei Principles, con la consequenza che egli potrebbe compromettere la tutela risarcitoria dei diritti findamentali, magari “ subordinandola a esigenze diverse,

${ }^{11}$ Enunciado 46 - Art. 944: a possibilidade de redução do montante da indenização em face do grau de culpa do agente, estabelecida no parágrafo único do art. 944 do novo Código Civil, deve ser interpretada restritivamente, por representar uma exceção ao princípio da reparação integral do dano.(Redação dada pelo Enunciado 380 aprovado na IV Jornada de Direito Civil) 
come quelle relative al mercato delle assicurazioni ${ }^{10}$.

Não obstante os embargos opostos por parte dos autores que tratam da responsabilidade civil no tocante aos espaços abertos pelo parágrafo único do artigo 944 para a prática de arbitrariedades judiciais, tal previsão vem sendo aplicada pelos tribunais pátrios. No entanto, deve ser considerada como medida que excepciona o princípio da reparação integral e, como tal, deve ser interpretada e aplicada de forma restritiva, posto que subtrai da vítima o direito à restauração do status quo ante (SCHREIBER, 2013, p. 45).

Corroborando com o entendimento acima, Monteiro Filho (2008, p. 74) destaca que:

[...] a correlação entre o caput e o parágrafo traduz-se, juridicamente pelo raciocínio regra-exceção. Seja por virtude do exame de força axiológica, seja pela análise da estrutura interna da norma, chega-se à idêntica constatação: a relação é de exceção para com regra do caput do dispositivo, que prevê a reparação integral do dano $[. .$.

O caráter de excepcionalidade da aplicação da redução equitativa da indenização, prevista no parágrafo único do artigo 944, foi confirmado pelo Enunciado 46, aprovado na I Jornada de Direito Civil ${ }^{11}$.

Para a aplicação da cláusula de redução, o próprio texto da lei determina a observância de certos requisitos, quais sejam: a culpa levíssima/leve do agente, o dano de significativa extensão e desproporção entre ambos.

São três os elementos expressamente previstos no parágrafo único do artigo 944 do Código Civil aos quais deve observância o julgador para aplicação da cláusula geral de redução: a gravidade da culpa, a extensão do dano e a excessiva desproporção entre ambos.

No tocante ao elemento culpa, diferentemente do que ocorre no artigo 186 do Código Civil - em que culpa e dolo foram equiparados para fim de caracterização do ato ilícito - no caso da aplicação da cláusula de redução esta deve ser concebida em sentido estrito, não sendo aplicável a redução legalmente prevista quando a conduta lesiva é praticada com dolo pelo agente (SANSEVERINO, 2010, p. 99).

Ao tratar da graduação da culpa, Stoco (2014, p. 222) mencionando a doutrina francesa como base para a classificação apresentada, define a culpa 
grave como sendo aquela contida na conduta em que o autor "sem 'querer' causar o dano, "comportou-se como se o tivesse querido", a culpa leve seria a ausência de diligência esperada do "homem médio" e, por fim, a culpa levíssima seria aquela falta cometida com inobservância de atenção que supera a média e somente seria adotada por pessoa de diligência muito acima do normal.

Atualmente prevalece o entendimento de que a culpa deve ser aferida a partir de critérios objetivos, ou seja, como um desvio do modelo de conduta esperado ou de um dever geral de cuidado. Desta forma, a aferição da culpa deve ser feita tomando como base o "homem médio", o qual não deve ser qualquer um, indiscriminadamente, mas aquele de mesma situação social e instrução que o ofensor, de forma que a aferição da culpa deverá ocorrer in concreto para que seja possível analisar em cada caso a magnitude da culpa do ofensor.

Adota-se, assim, no direito brasileiro, como regra, uma concepção objetiva mitigada de culpa, tanto para a responsabilidade contratual como para a extracontratual, tendo em conta o padrão de comportamento do homem médio, mas considerando circunstâncias concretas como o meio social, cultural e profissional em que o agente está inserido. (SANSEVERINO, 2010, p. 105)

Daniel Levy defende, ainda, "que houve verdadeiro equívoco do legislador pátrio na elaboração do parágrafo" (Levy, 2006, p. 92), afirmando que o vocábulo "culpa" foi utilizado com imprecisão pelo legislador, devendo ser interpretado em seu aspecto puramente objetivo, aproximando a culpa do agente (elemento subjetivo) da própria conduta (elemento objetivo). Segundo referido autor, "a conduta humana realiza-se em duas fases: a primeira deriva de um elemento subjetivo do agente que é traduzido na culpa; a segunda fase consiste na execução da ação real [...] a conduta humana é a exteriorização da culpa" (LEVY, 2006, p. 93), sendo assim, "considerando-se, outrossim, que a conduta do agente é um dos elementos do nexo causal; então será possível aplicar o parágrafo único do artigo 944 apenas com base nesta relação entre a

${ }^{12}$ Segundo Sanseverino (2010, p. 109) "a proporcionalidade tem sido examinada na concretização de direitos fundamentais, verificando-se, em primeiro lugar, que o meio deve conduzir à realização do fim (adequação). Em segundo lugar, havendo vários meios disponíveis, deve-se escolher o menos restritivo dos direitos fundamentais afetados (necessidade). Em terceiro lugar, o grau de importância de realização do fim almejado deve ser proporcional às desvantagens causadas pela escolha do meio, que restringe um direito fundamental (proporcionalidade em sentido estrito)." 
conduta do agente, inserida no nexo causal, e o dano" (idem, p. 94).

Todavia, não é esse o posicionamento majoritário, eis que a maior parte da doutrina entende que se deve aferir o grau de culpa do agente - e não a mera relação de causalidade - para fins de aplicação da cláusula de redução.

No que se refere à extensão dos danos como elemento a ser observado para a aplicação da redução da indenização, é necessário aferir a extensão objetiva e econômica do prejuízo suportado pela vítima, de forma que seja possível evidenciar a desproporção entre este e a culpa do autor, outro elemento necessário à concreção da redução.

A excessiva desproporção, também mencionada no dispositivo legal, deve ser avaliada a partir dos princípios da razoabilidade, o qual difere do princípio da proporcionalidade, já que enquanto esta última será sempre analisada em abstrato - procedendo-se à aferição em tese da necessidade, adequação e proporcionalidade em sentido estrito ${ }^{12}$ da medida adotada (no caso da responsabilidade civil, a indenização) - a análise da razoabilidade, ao contrário, deverá ser realizada in concreto, e ser concebida sob duas perspectivas: como equidade (sentido aristotélico-tomista), vista como instrumento de harmonização entre a norma e o caso concreto; e como equivalência, promovendo a análise da correspondência entre a medida adotada (indenização) e o critério utilizado para tanto (culpabilidade do agente) (SANSEVERINO, 2010, p. 111). O citado autor (2010, p. 111) alude ainda que:

A norma do parágrafo único do art. 944 do $\mathrm{CC} / 2002$, ao fazer referência expressa à "excessiva desproporção" entre a culpabilidade e o dano, apesar de conduzir o raciocínio do intérprete para a proporcionalidade, amolda-se melhor ao postulado da razoabilidade.

Não se está a estabelecer uma relação entre meio e fim no plano abstrato, como se faz com a utilização do postulado da proporcionalidade, mas de uma relação entre critério e medida para se alcançar uma relação de equidade ou equivalência entre a indenização (medida) e a culpabilidade do responsável (critério). Ou seja, a referência à "desproporção" é feita com a conotação de proporcionalidade em sentido estrito.

A noção de equidade que deve orientar o julgador para a aplicação da cláusula de redução sempre deverá decorrer da análise dos elementos que 
compõem o caso concreto, avaliando se a minoração da indenização é cabível e necessária, e se tal medida compensa o sacrifício do princípio da reparação integral e o prejuízo que será suportado exclusivamente pela vítima (diferença entre o valor do dano e da reparação).

Voltando os olhos para a questão referente à aplicação da cláusula geral de redução às hipóteses de responsabilidade contratual, em que o dever jurídico violado se funda em um instrumento contratual, tem-se que da análise dos elementos que caracterizam o dever de indenizar nessas circunstâncias tornam possível a utilização do parágrafo único do artigo 944 do Código Civil, na exata medida em que verificada a necessária desproporção entre o dano e a culpa do agente.

Nesses casos, deve-se destacar que a culpa do contratante não possui um viés moral, sendo caracterizada pelo simples inadimplemento voluntário das obrigações pactuadas ou, ainda, pela quebra dos deveres colaterais oriundos da relação jurídica contratual, conforme tratado nos itens anteriores. Evidentemente que, havendo dolo na conduta do contratante ofensor, não há como admitir a aplicação da redução equitativa da indenização, tal como é uníssona a doutrina em relação ao cabimento deste recurso em relação aos danos oriundos de responsabilidade extracontratual.

Os danos, por sua vez, devem ser apurados a título de perdas e danos ou mediante a utilização da cláusula penal, enquanto fórmula de pré-fixação de danos pelas partes, sendo que em ambas as hipóteses sua aferição refletiria os danos de natureza patrimonial.

A desproporção entre a culpa e o dano deve ser objeto de avaliação em concreto pelo julgador, a partir do princípio da razoabilidade, a qual deve ser concebida sob a perspectiva da equidade, enquanto instrumento de harmonização entre a norma e o caso concreto, e como equivalência, a fim de promover a correspondência entre a indenização e a real culpabilidade do agente, conforme prevê Sanseverino (2010, p. 111).

Cabe destacar que não raras vezes medidas semelhantes àquelas previstas no parágrafo único do artigo 944 do Código Civil são adotadas pelo Poder Judiciário, a exemplo da redução do quantum da cláusula penal quando esta se mostra abusiva em face das circunstâncias ou da extensão do inadimplemento.

Tal situação, entretanto, difere do exposto na cláusula geral de redução em decorrência da ausência de necessidade da observância dos elementos essenciais de aplicação do mencionado dispositivo legal. 


\section{CONCLUSÃO}

Os contornos e limites da culpa na responsabilidade contratual ainda despertam nos dias atuais calorosos debates. A opção do legislador pátrio pela desconsideração da culpa, em regra, para fins de quantificação da indenização, definindo a extensão do dano como parâmetro para o ressarcimento, levou ao advento da ideia de que o mero inadimplemento, a simples inobservância voluntária do pacto firmado anteriormente dentro dos limites da autonomia privada, seria suficiente para ensejar a completa reparação dos danos à parte contrária.

A despeito da clara regra trazida no caput do artigo 944 do Código Civil, com objetivo de facilitar a quantificação dos prejuízos decorrentes do inadimplemento contratual, a exceção contida no parágrafo único deste mesmo dispositivo coloca em xeque a sistemática da culpa na responsabilidade contratual, pois, se outrora relegada à mera verificação do nascimento do dever de indenizar, quando confrontada com a cláusula geral de redução da indenização, passa a ter relevância na apuração do quantum debeatur, relativizando a reparação integral buscada como regra no ordenamento jurídico brasileiro.

A princípio, a aplicação da cláusula geral de redução da indenização - a qual possui como elemento essencial a desproporção entre a culpa do agente e o dano causado - parece inconciliável com os elementos da responsabilidade contratual, mormente se considerada a culpa como decorrente do mero inadimplemento.

Todavia, parece razoável, com base nos argumentos levantados pela doutrina que a avaliação da desproporção entre culpa e dano, exigida como requisito para a aplicação da redução equitativa da indenização, deve ser realizada de forma diferente da adotada na responsabilidade extracontratual subjetiva, eis que nesta é possível diferenciar (ainda que irrelevante para o surgimento do dever de indenizar) os graus de culpa do agente na prática do ato ilícito.

Na responsabilidade contratual, contudo, a culpa do contratante ofensor não possui um viés moral, se caracterizando pelo inadimplemento voluntário das obrigações pactuadas ou pela quebra dos deveres colaterais oriundos da relação jurídica contratual. Tal concepção de culpa, não se confunde com o dolo, que subsiste na seara da responsabilidade contratual, caso haja por parte do contratante a intenção de causar o dano oriundo do inadimplemento contratual. 
Assim como na responsabilidade extracontratual, não há que se falar em redução da indenização se verificado o dolo, pois nestas situações além da voluntariedade da conduta se está diante do direcionamento desta para a produção do resultado.

Desta forma, na responsabilidade civil por danos contratuais, ao contrário do que ocorre na responsabilidade aquiliana, a aplicação do parágrafo único do artigo 944 do Código Civil tem como elemento secundário a gradação da culpa stricto sensu - visto que esta se configura pelo próprio inadimplemento voluntário do contrato - se voltando para a verificação da existência de excessivo ônus ao autor do dano na reparação, de modo a evitar que a indenização exceda os limites da função satifativa e importe no enriquecimento sem causa do credor.

A apuração dos prejuízos, necessária ao juízo de razoabilidade exigido pela cláusula geral de redução da indenização, pode ser realizada não somente sob a forma de perdas e danos (compostos pelos danos emergentes e lucros cessantes), mas também mediante a utilização da cláusula penal, concebida como fórmula de pré-fixação de danos pelas partes, sendo que em ambas as hipóteses sua aferição refletiria os danos de natureza patrimonial.

Por fim, a desproporção entre a culpa e o dano deve ser objeto de análise em concreto pelo julgador, a partir do princípio da razoabilidade, esta compreendida sob a perspectiva da equidade, enquanto instrumento de harmonização entre a norma e o caso concreto, assegurando a realização da Justiça de forma individualizada, e como equivalência, a fim de promover a correspondência entre a indenização e a real culpabilidade do agente.

\section{REFERÊNCIAS}

ALVIM, Agostinho. Da inexecução das obrigações e suas consequências.

5. ed. São Paulo: Saraiva, 1980.

ALSINA, Jorge Bustamante. Teoría general de la responsabilidad civil. 9. ed. Buenos Aires, Abeledo-Perrot, 1997.

BRASIL. Lei $\mathbf{n}^{\mathbf{0}} \mathbf{1 0 . 4 0 6}$, de 10 de janeiro de 2002. Institui o Código Civil. Disponível em: <http://www.planalto.gov.br/ccivil_03/leis/2002/ L10406compilada.htm>. Acesso em 25 set. 2015.

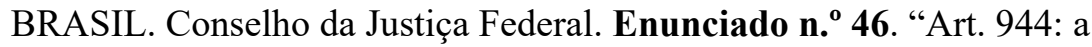


possibilidade de redução do montante da indenização em face do grau de culpa do agente, estabelecida no parágrafo único do art. 944 do novo código civil, deve ser interpretada restritivamente, por representar uma exceção ao princípio da reparação integral do dano.” I Jornada de Direito Civil, Brasília, 2002. Disponível em: <http:/www.stj.jus.br/publicacaoseriada/ index.php/jornada/article/viewFile/2607/2685>. Acesso em: 01 out. 2015.

BRASIL. Conselho da Justiça Federal. Enunciado n. ${ }^{0}$ 380. “A. 944:

atribui-se nova redação ao enunciado n. 46 da i jornada de direito civil, pela supressão da parte final: "não se aplicando às hipóteses de responsabilidade objetiva'”. IV Jornada de Direito Civil, Brasília, 2006. Disponível em: <http://www.stj.jus.br/publicacaoseriada/index.php/jornada/article/ viewFile/2626/2701>. Acesso em: 01 out. 2015.

BRASIL. Constituição da República Federativa do Brasil. Diário Oficial da União: Poder Legislativo, Brasília, 1988. Disponível em: $<$ http://www. planalto.gov.br/ccivil_03/constituicao/ConstituicaoCompilado.htm>. Acesso em: 01 out. 2015.

CAFAGGI, Fabrizio. Profili di relazionalitá della colpa: contributo ad una teoria della responsabilità extracontratuale. Itália: Ed. CEDAM, 1996.

CALDERALE, Alfredo. Diritto privato e codificazione in Brasile. Milão: Giuffrè, 2005.

CAVALIERI FILHO, Sérgio. Programa de responsabilidade civil. 10. ed. São Paulo: Atlas, 2012.

DINIZ, Maria Helena. Curso de direito civil brasileiro. São Paulo: Saraiva, 2004. v.2.

FARIAS, Cristiano Chaves de; ROSENVALD, Nelson. Direito das famílias. Rio de Janeiro: Lúmen Júris, 2008.

GOMES, Orlando. Obrigações. Rio de Janeiro: Forense, 2007.

GONÇALVES, Carlos Roberto. Direito civil brasileiro. São Paulo: Saraiva, 
2008. v.3.

LEVY, Daniel. A “culpa” no artigo 944, parágrafo único, do Código Civil. Direito, Estado e Sociedade, Rio de Janeiro, n. 28, p. 86-102, jan./jun. 2006.

LIMA, Alvino. Culpa e risco. São Paulo: Editora Revista dos Tribunais, 1960.

MAZEAUD, Henri; MAZEAUD, Jean; MAZEAUD, Leon. Leçons de droit civil. Tradução por Santiago Sentis Melendo. Buenos Aires: Ediciones Jurídicas Europa-América, 1969.

MONTEIRO, Washington de Barros. Curso de direito civil. São Paulo: Saraiva, 2007, v.4.

MONTEIRO FILHO, Carlos Edison do Rêgo. Artigo 944 do Código Civil: o problema da mitigação do princípio da reparação integral. Revista de Direito da Procuradoria Geral do Estado do Rio de Janeiro, v. 63, p. 6994, 2008.

MONTENEGRO, Antonio Lindbergh C. Ressarcimento de danos: pessoais e materiais. 6. ed. ampl. e atual. Rio de Janeiro: Lumen Iuris, 1999.

PARGENDLER, Mariana. O caráter exemplar da indenização e o Direito Civil Brasileiro: pena privada ou punitive damages. Disponível em: $<$ http:// lanic.utexas.edu/project/etext/llilas/ilassa/2004/pargendler.pdf $>$. Acesso em: 13 set. 2015.

SANSEVERINO, Paulo de Tarso Vieira. Princípio da reparação integral: indenização no Código Civil. São Paulo: Saraiva, 2010.

SANTOS, Camila Fernandes; SAMPAIO JÚNIOR, Rodolpho Barreto. Efeitos jurídicos da violação positiva do contrato: indenização ou resolução contratual? In: Direito Civil I. XXIII Congresso Brasileiro do CONPEDI/UFPB. Disponível em: <http://publicadireito.com.br/ artigos/?cod=2f58929950c0c51f $>$. Acesso em; 15 out. 2015. 
SCHREIBER, Anderson. Novos paradigmas da responsabilidade civil - da erosão dos filtros da reparação à diluição dos danos. 5. ed. São Paulo: Atlas, 2013.

SILVA, Jorge Cesar Ferreira da. A boa-fé e a violação positiva do contrato. Rio de Janeiro: Renovar, 2002.

STOCO, Rui. Tratado de responsabilidade civil: doutrina e jurisprudência. 8.ed. São Paulo: Revista dos Tribunais, 2011.

VISENTINI, Giovanna. Tratado de la responsabilidad civil. La culpa como critério de imputación de la responsabilidad. Incumprimento e responsabilidade do devedor. Culpa aquiliana e culpa contratual. A culpa profissional. O dolo. Trad. Aída Kemeljamer de Carlucci. Buenos Aires: Editorial Astrea, 1999. v. 1.

Como citar: AMARAL, Ana Cláudia Corrêa Zuin Mattos do; PONTELI, Nathalia Nunes. Responsabilidade contratual e cláusula geral de redução da indenização à luz da teoria contemporânea do inadimplemento. Scientia Iuris, Londrina, v. 20, n. 1, p.165-193, abr. 2016. DOI: 10.5433/2178-8189.2016v20n1p165. ISSN: 2178-8189.

Submetido em 03/03/2016

Aprovado em 16/03/2016 